\title{
連続変形法を用いた多機系統安定化のための 発電機励磁制御
}

\author{
正員松下邦雄 (四国総 研) \\ 正嘪大松繁 (大阪府立大)
}

\section{Excitation Control of Generators for the Multi-Machine Power System by the Homotopy Method}

\begin{abstract}
Kunio Matusita, Member (Sikoku Research Institute Inc.), Sigeru Omatu, Member (University of Osaka Prefecture)
\end{abstract}

It is important to consider a stabilization problem for a large scale power system. In this paper, we use a dynamic compensator based on observer theory such that desired poles are placed for a closed loop multi. machine power system. Since dimension of the system is large, it is difficult to apply a conventional dynamic compensator method to an excitation control problem for a multi-machine power system.

We introduce the homotopy method to solve fundamental nonlinear equations which are required for observer synthesis. To show the effectiveness of the proposed method, we consider an excitation control of generators for a multi-machine power system.

From the simulation result, it is shown that the present method is useful to stabilize a multi-machine power system.

キーワード：多機系統, 安定化制御, 励磁制御, 動的補償器, 連続变形法

\section{1. まえがき}

近年，電力系統はその規模が拡大し，複雑化する傾向を 強め, 更に大容量電源の集中化や遠滆地化に伴い，大電力 の長距離輸送化を余儀なくされている。このため, 電力系 統の安定度，とりわけ日常的な系統運用に大きな影響を与 える動態安定度の維持が重要な課題となっている。動態安 定度を維持するために，系統安定化装置(Power System Stabilizer；以下PSS と略記）が赛用に供されており，そ の設計法についての論文も数多く発表されている(1)-(5)。 文献(1)〜(4)は1台の発電機についてのものであり，文 献 $(5)$ 江複数の発電機に関卞る研究である。特に, 文献 （5）現実のPSSに即したものであり，実際にも広く利 用されている。しかし，この手法は周波数応答法を用い， ボード線図を介した間接的なものであり，近似的な計算法 である。また文献（5)はループダインが小であることを前 提として，非干渉制御系が成立しているとの前提条件に基 づいているため，多入力ー多出力系に対する取扱いが十分 なものとはなっていない。著者らは，多入力一多出力系の 励磁制御を，固有值感度行列を線形計画法を用いて設計す る手法について既に報告した(6)。この方法は励磁制御系の
構造が任意であるため，分散制御系への適用などの幅広い 応用が期待できる。しかし，制御パラメータと閉ループ系 の固有值は非線形関係にあるため，パラメータの収束性は その初期值設定に大きく依存していた。従って, 文献 (6) のように制御パラメータの概略値があらかじめ既知である ような場合に対しては有効であるが，それ以外の場合には 試行錯誤に長い時間を要していた。

本論文では, 動的補償器 (Dynamic Compensator; 以 下DC と略記）に基づいた極配㯰を行うことによって，多 入力一多出力动磁制御系構成し, 多機系統の安定化を図 ることを試みる。DCの計算法は既に確立されている が(7)-(9)，大規模秀統に対しては，計算機の有効桁数の制 限により計算精度が著しく劣化し，その手法は実用的な方 法となっていない。特に,ここでは, DCの設計に際して 励磁制御系に含ま机る飽和要素の影響を考慮し, DC の出 力があらかじめ与えられた範团内に拉忠るようにした。 そこで本論文では，DCの設計理論に関する基本的な関係 を大域的な求解が期待できる連続変形法による数值計算で 直接求めることとする。最後に，シミュレーションにより 本手法の有効性を定䥣的に検泟する。 


\section{2. 発電機励磁制御への DC の適用}

$\langle 2 \cdot 1\rangle$ 多機系統の状態方程式 $\quad N$ 機 大母線含含電力系統の電力動摇方程式花平衡点の近傍て 線形化した方程式は次式で表きれる(10)。

$$
\begin{aligned}
& \dot{\boldsymbol{x}}(t)=\boldsymbol{A} \boldsymbol{x}(t)+\boldsymbol{B} \boldsymbol{u}(t) \\
& \boldsymbol{y}(t)=\boldsymbol{C} \boldsymbol{x}(t) \cdots \ldots \ldots \ldots
\end{aligned}
$$

ここに, $x(t)$ は次式で与えられる $n$ 次元状態ベクトル である。

$$
\begin{aligned}
& \boldsymbol{x}(t)=\operatorname{col}\left[\boldsymbol{x}_{G 1}(t), \cdots, \boldsymbol{x}_{G N}(t), \boldsymbol{x}_{F_{1}}(t), \cdots, x_{F_{N}}(t)\right] \\
& x_{C k}(t)=\operatorname{col}\left(\Delta e_{d k}^{\prime}(t), \Delta e_{d k}^{\prime \prime}(t), \Delta \epsilon_{q k}^{\prime}(t),\right. \\
& \left.\Delta e_{q k}^{\prime \prime}(t), \Delta \omega_{k}(t), \Delta \hat{\delta}_{k}(t)\right]
\end{aligned}
$$
なお， $\operatorname{col}[\cdot]$ は列ベタトルを，添字 $k$ は番目の発電機 であることを，また，」は平衡点からの偏差であることを 示している。 $y(t)$ は $m$ 次元出力ベクトル, $\boldsymbol{u}(t)$ は $r$ 次 元入力ベクトルを示し, $A, B, C$ は, 各々, 次の上うな係 数行列を示している。

$$
\boldsymbol{A} \in R^{n \times n}, \quad \boldsymbol{B} \in R^{n \ltimes r}, \quad C \in R^{m \times n}
$$

系統安定化の対象となるシステムの係数行列 $A$ の固有 值の実部は，いくつかが正であるか，または絶対值が小さ い負值である。このような性筫をもつシステムに対し，次 のような DC を適用して安定化を図る。

〈2・2〉 DC の方程式 DC の構造に関する方程式は次 のとおりである(9)。

$$
\begin{aligned}
& \dot{z}(t)=\boldsymbol{D} z(t)+\boldsymbol{E} \boldsymbol{y}(t) \\
& \boldsymbol{u}(t)=\boldsymbol{F} z(t)+\boldsymbol{G} \boldsymbol{y}(t)
\end{aligned}
$$

ただし， $z(t)$ は $q$ 次元ベクトルで, DC内部の状態変数を 表している。また，D, $E, F, G$ 快，各々，次の上うな係 数行列を示している。

$$
\boldsymbol{D} \in R^{q \times q}, \quad \boldsymbol{E} \in R^{q \times m}, \quad \boldsymbol{F} \in R^{r \times q}, \quad \boldsymbol{G} \in R^{r \times m}
$$

(1)，(2)式で記述されるシステムと(3)，(4)式で与光 られるDC 結合した閉ループ系が安定であるためには次 の条件が満たされなければならない。

$$
\begin{aligned}
& \boldsymbol{G C}+\boldsymbol{F} \boldsymbol{U}=\boldsymbol{K} \\
& E C+D U=U(A+B K) \\
& D-U B F=\boldsymbol{A}_{d} \\
& \boldsymbol{K} \in R^{r \times n}: A \text { O固有值を希望する值に移動させ } \\
& \text { るための状態フィードバック行列 }
\end{aligned}
$$

\footnotetext{
電学論C, 115 巻 10 号, 平成 7 年
}

$$
\begin{aligned}
& \boldsymbol{A}_{d} \in R^{q \times q}: \text { DC } \text { の固有值在指定する行列 } \\
& U \in R^{q \times n}: \text { 未知の定数行列 }
\end{aligned}
$$

一般に，発電機の励磁制御系には飽和要素が数多々含まれ ているため，過大な制御入力 $\boldsymbol{u}(t)$ を印加寸ると，これら の飽和要素の影響が大きくなり，線形システムの仮定が成 立しなくなる。その結果，安定化制御の効果が搷なわれる こともあり得る(6)。従って，励磁制御に用いるDCは，て きるだけ小さな $\boldsymbol{u}(t)$ となるような係数行列 $D, E, F, G$ を見いだす必要がある。

〈2・3〉 新しい DC の設計法 DC の設計法について は，システムとDCの固有多項式を利用した方法などがあ るが(7) こ(8)，これらの次数が高いとコンピュータの有效桁 数の制約から計算精度が著しく劣化する。また，さきに述 ベたように $\boldsymbol{u}(t)$ が小さくなるような DCパラメー夕が設 計できる保証はない。そこで， $\boldsymbol{u}(t)$ が極力小さくなるよ うに，DCを設計することを試みる。

これは， $\boldsymbol{u}(t)$ の大きさ指標としてノルム\|u(t)\|を用 い,このノルムが小さくなるような $\mathrm{DC}$ の係数行列 $D, E$, $F, G$ ならびに末知定数行列 $U$ 在 (5)〜 (7) 式加ら数值 計算を直接行って求め上うとする方法である。(5)〜 (7) 式老満足するDCにおいては $z(t)$ と $x(t)$ との間には次式 が成立する(11)。

$$
\boldsymbol{z}(t)-\boldsymbol{U} \boldsymbol{x}(t)=e^{\wedge t}\{\boldsymbol{z}(0)-\boldsymbol{U} \boldsymbol{x}(0)\}
$$

$z(0), x(0): z(t), x(t)$ 0初期值

$\|\boldsymbol{u}(t)\|$ 洁(2)，(4)，(5)式と（8)式の関係を用いると， 次式の上うになる。

$$
\begin{aligned}
\|\boldsymbol{u}(t)\| \leq\|\boldsymbol{K}\| \cdot\|\boldsymbol{x}(t)\|+\|\boldsymbol{F}\| \cdot \\
\left\|e^{\wedge d t}\{z(0)-\boldsymbol{U} \boldsymbol{x}(0)\}\right\| \cdot .
\end{aligned}
$$

電力系統の安定性を検討するうえでは，送電線事故に続 く送電線開放による事故除去など大さな外乱が発生した直 後の状態が $x(0)$ である。一般に $\boldsymbol{x}(0) \neq 0$ であるが，外乱 の継続時間は 70〜100 ms 程度であることから，この間の DC の応答量は小さいと考えられるので， $z(0) \fallingdotseq 0$ とする。

この結果，(9)式は次のように整理できる。

$$
\begin{array}{r}
\|\boldsymbol{u}(t)\| \leq\|\boldsymbol{K}\| \cdot\|\boldsymbol{x}(t)\|+\|\boldsymbol{F}\| \cdot \\
\left\|e^{\wedge a t}\right\| \cdot\|\boldsymbol{U}\| \cdot\|\boldsymbol{x}(0)\|
\end{array}
$$

ここで， $\boldsymbol{K}$ は与えられた行列であるから，\|F\|,\|U\|を 小さくするならば\|u(t)\|を小さくすることが可能になる。 (10)式のノルムとして次のようなノルムが定義でき $3^{(12)}$ 。

$$
\begin{aligned}
& \|\boldsymbol{H}\|_{1} \triangleq \max _{1 \cong, 1} \sum_{i=1}^{m}\left|h_{i, 3}\right| \\
& \text { ここに, } \boldsymbol{H}: \text { 一般の } n \times n \text { 行列 }
\end{aligned}
$$

ただし，実際のDCの設計にあたりこのようなノルムを用 いるの誩十算が非常に複雑になるので，ここでは

$$
\|\boldsymbol{H}\|_{1} \leq m \cdot \max _{i=j \leq n}\left|h_{i j}\right|
$$

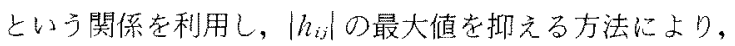
間接的に行列のノルムを小さくする方法を用いた。

(5) 〜 (7) 式右辺の $\boldsymbol{K}, \boldsymbol{A}_{a}$ は定数行列であり，このう 
ち $\boldsymbol{K}$ は出力変数の固有ベタトルを用いた計算アルゴリズ ム (13) 老用いれば，比較的簡単にしかも数值的に安定な解 在得ることができる。また， $\Lambda_{i}$ の要素 $\lambda_{i j}(i, j=1,2, \cdots$, q）を次つようにおく。

$$
\left.\begin{array}{rlrl}
\lambda_{i j} & =\mathrm{DC} \text { の固有伹 } & & (i=j) \\
& =0 & & (i<j) \\
& =\text { 任意 } & & (i>j)
\end{array}\right\}
$$

(13)式の第3 番面の条件を考虑すると，（5)（７）式にお いて, 解くべき方程式抒よび变数の個数を, 各々, $a_{0}, b_{0}$ とすると，

$$
\left.\begin{array}{l}
a_{0}=n(r+q)+q(q+1) / 2 \\
b_{0}=q(m+n+r+q)+m r
\end{array}\right\}
$$

となる。(5)〜(7)式を解くには， $a_{0} \leq b_{0}$ という条件が 必要であるから，次式が成立する。

$$
q \geq \frac{r(n-m)}{m+r+\{(q-1) / 2\}}
$$

(5)〜（7) 式のような非線形連立方程式の解法として知 られているのはニュートン法である。これは，解の十分良 い近似值を初期值として与え扎代良好な収束性を有する が，それ以外の場合に収束解を得ることは一般に困難であ る。

同樣に，パウエル法などの非線形計画法も大域的な最適 解を得るのは困難であるばかりでなく，方程式の次数が大 きくなると極端に計算量が增大する。本論女では，第 3 章 に示すように，大域的な収束性に優れている連続変形法を 適用することとする。

\section{3. 連続変形法による非線形連立方程式の解法}

\section{〈3.1〉連続変形法連続变形法は方程式}

$$
f(x)=0
$$

を直接解く代わりに，例えば

$$
\boldsymbol{h}(x, \tau)=\boldsymbol{f}(\boldsymbol{x})-(1-\tau) \boldsymbol{f}\left(\boldsymbol{x}^{(0)}\right)
$$

の上うな関数を構成し， $\tau$ を $[0,1]$ 区間で段階的に変化さ せながら，逐次，次式を解いていくものである化。ただ

し， $x$ は変数べタトルを示している。

$$
h(x, \tau)=0
$$

(18)式を解くにはニュートン法を用いる。連続変形法で

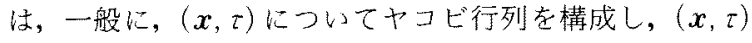
に対する修正量 $(\Delta x, \Delta \tau)$ を求める方法が用いられている。 本論文では簡単のため, $\tau$ の増加量 $\Delta \tau$ を, その出発值は $10^{-4}$ とし, その最大は 0.05 として, 解の収束状況に応し

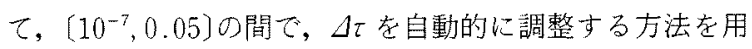
いる。

二ュートン法により(18)式を解くには，多数回の連立一 次方程式を計算する必要がある。通常, 連立一次方程式の 計算量は方程式の次数の 3 乘オーダで增大するといわれて いる(15)。このため, システムの次数が高くなり，これに 伴って連立一次方程式の次数が高くなると急激に計算量が 増大する。そこで，連立一次方程式の次数を增加させず に, 効率良く(5)〜 ( 7) 式を解くための新しい方法につい
て次節で述る。

〈3.2〉相似变換 (6)式の右辺の行列を相似変換し てブロック対角行列に裂換する。ここでは，実変換行列 $T \in R^{n \times n}$ を用いて次のような操作を行う。

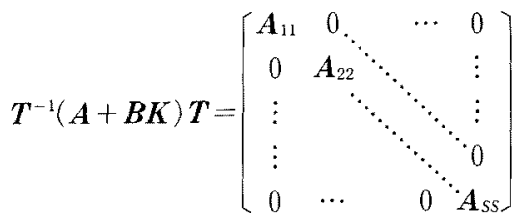

ここで， $\boldsymbol{A}_{k k}$ は， $k$ 番目の固有值が単根であれば，その 固有值, 複素根 $\alpha_{k} \pm j \beta_{k}$ であれば, 次のような $2 \times 2$ の行 列を示す。

$$
A_{k k}=\left[\begin{array}{cc}
\alpha_{k} & \beta_{k} \\
-\beta_{k} & \alpha_{k}
\end{array}\right]
$$

この変換により, (5)〜 (7)式の $C, B, K$ は, 各々, $C \rightarrow C T, B \rightarrow T^{-1} B, K \rightarrow K T$ ように変換される。上述 の相似変換の結果を示守ために, 行列の上側に一を付け b。

（5）〜（7）式にニュートン法を適用したとき，修正方程 式は次式となる。

$$
\begin{aligned}
& \Delta G \bar{C}+\Delta F U_{0}+F_{0} \Delta U=\Delta \varepsilon_{1} \ldots \ldots \ldots \ldots \ldots \ldots \ldots \\
& \Delta E \bar{C}+\Delta D U_{0}+D_{0} \Delta U-\Delta U(\bar{A}+B \bar{B})=\Delta \varepsilon_{2}
\end{aligned}
$$
ただし，

$$
\begin{aligned}
& \Delta \varepsilon_{1}=\bar{K}-G_{0} \bar{C}-F_{0} U_{0} \\
& \Delta \varepsilon_{2}=U_{0}(\overline{A+B} \bar{K})-E_{0} \bar{C}-D_{0} U_{0} \\
& \Delta \varepsilon_{3}=\wedge_{\alpha}-D_{0}+U_{0} \bar{B} F_{0}
\end{aligned}
$$

$U_{0}, E_{0}, F_{0}, G_{0}$ : 初期値, または前段の計算で求 められた近似值

なお，(23)式では対角要素を含む行列の上三角部分が解く べき方程式の対象となる。(22)式について， $\Delta U$ の第 $k$ 列目の要素に関連する方程式注次のようになる。

(1) 第 $k$ 番目の固有值が单根 $\left(\alpha_{k}\right)$ の場合

$$
\Delta \boldsymbol{E} \overline{\boldsymbol{C}}_{k}+\Delta \boldsymbol{D} \boldsymbol{U}_{0 k}+\boldsymbol{D}_{0} \Delta \boldsymbol{U}_{k}-\operatorname{diag}\left\{\alpha_{k}\right\} \Delta \boldsymbol{U}_{k}=\Delta \boldsymbol{\varepsilon}_{2 k}
$$

（2）第 $k$ 番目の固有值が複素根 $\left(\alpha_{k}+j \beta_{k}\right)$ の場合

$$
\begin{aligned}
& {\left[\begin{array}{c}
\Delta E \bar{C}_{k}+\Delta D U_{0 k} \\
\Delta E \bar{C}_{k+1}+\Delta D U_{0 k+1}
\end{array}\right]+\left\{\left[\begin{array}{cc}
D_{0} & 0 \\
0 & D_{0}
\end{array}\right\}\right.} \\
& \left.-\left[\begin{array}{cc}
\alpha_{k} I_{q}-\beta_{k} I_{q} \\
\beta_{k} I_{q} & \alpha_{k} I_{q}
\end{array}\right]\right\}\left[\begin{array}{c}
\Delta \boldsymbol{U}_{k} \\
\Delta \boldsymbol{U}_{k+1}
\end{array}\right]=\left[\begin{array}{c}
\Delta \boldsymbol{\varepsilon}_{2 k} \\
\Delta \boldsymbol{\varepsilon}_{2 k+1}
\end{array}\right]
\end{aligned}
$$

ここで, $I_{q}: q \times q$ の単位行列, $\bar{C}_{k}, U_{o k}, \Delta \varepsilon_{2 k}:$

各々 $\bar{C}, U_{0}, \varepsilon_{2}$ の第 $k$ 番目の列べクトル いま, $\Delta \boldsymbol{D}, \Delta \boldsymbol{E}, \Delta \boldsymbol{F}, \Delta \boldsymbol{G}$ の行ベクトルを，各々 $\Delta \boldsymbol{D}_{k}(k$ $=1, \cdots, q), \Delta \boldsymbol{E}_{k}(k=1, \cdots, q), \Delta \boldsymbol{F}_{k}(k=1, \cdots, r), \Delta \boldsymbol{G}_{k}(k=1$. $\cdots, r)$ と，次の上うなべクトルを定義する。

$$
\begin{aligned}
& \Delta \tilde{\boldsymbol{D}} \triangleq \operatorname{col}\left[\Delta \boldsymbol{D}_{1}^{T} \cdots \Delta \boldsymbol{D}_{q}^{T}\right], \Delta \tilde{\boldsymbol{E}} \triangleq \operatorname{col}\left[\Delta \boldsymbol{E}_{1}^{T} \cdots \Delta \boldsymbol{E}_{q}^{T}\right] \\
& \Delta \tilde{\boldsymbol{F}} \triangleq \operatorname{col}\left[\Delta \boldsymbol{F}_{1}^{T} \cdots \Delta \boldsymbol{F}_{r}^{T}\right], \Delta \tilde{G} \triangleq \operatorname{col}\left[\Delta \boldsymbol{G}_{1}^{T} \cdots \Delta \boldsymbol{G}_{r}^{T}\right) \\
& \Delta \tilde{\boldsymbol{U}} \triangleq \operatorname{col}\left[\Delta \boldsymbol{U}_{1} \cdots \Delta \boldsymbol{U}_{n}\right]
\end{aligned}
$$


(24)，(25)式から， $\Delta U_{k} ま た は\left(\Delta U_{k}, \Delta U_{k+1}\right) を \Delta \tilde{D}, \Delta \tilde{E}$ について解くことができる。これを逐次的に(21)，(23)式 に代入して整理する上, 最終的に次のような二つの方程式 が得られる (付録 1 参照)。

$$
\begin{aligned}
& A_{1} \boldsymbol{X}=\Delta \varepsilon_{1}^{*} \ldots \ldots \ldots \\
& \Delta \tilde{U}=A_{2} \boldsymbol{X}+\Delta \varepsilon_{2}^{*}
\end{aligned}
$$

$$
\text { ただし, } A_{1} \in R^{a \times b}, A_{2} \in R^{2 \times b}
$$$$
X=\operatorname{col}(\Delta \tilde{G} \quad \Delta \tilde{F} \quad \Delta \tilde{E} \quad \Delta \tilde{D}] \in R^{b}
$$$$
\Delta \varepsilon_{1}^{*}, \Delta \varepsilon_{2}^{*}: \text { 定数べクトル }
$$$$
a=n r+q(q+1) / 2
$$$$
b=q(q+m+r)+m r
$$$$
l=q n
$$

なお，連続変形法を適用する場合には，(17)式の右辺第 2 項も考慮して，上述の定数ベクトルを計算する必要があ る。

本手法に扔いて，解くべき方程式は(26)式であり，その 結果受けて(27)式加 $\Delta \bar{U}$ を求める。本手法における 万程式の次数拉上び変数の数屿，(28)式の $a, b$ である。 (21) (23) 式直接解く場合の方程式の次数は，(14)式の $a_{0}$ であるから，いま， $n \gg q$ とすると， $a_{0} \fallingdotseq n(q+r), a \doteqdot$ $n r$ と近似できる。従って，本手法による方程式の次数の 低隇率は， $a / a_{0} \fallingdotseq N(q+r)$ となる。特に，多入力一多出力 系注，1 入力-多出力系に変換できるから ${ }^{(9)}, a / a_{0} \fallingdotseq 1 /(q$ +1)となる。

このように，本手法は方程式の次数を大幅に低減できる 特長をもっている。しかし, $\Delta \tilde{U}$ は $\Delta \tilde{D}, \Delta \tilde{E}, \Delta \tilde{\boldsymbol{F}}, \Delta \tilde{\boldsymbol{G}}$ の 值に対し，直接的な影響を受けるため，大きな值となる場 合がある。特に(24)式または(25)式からわかるように $\Delta U_{k}$ または $\left(\Delta U_{k}, \Delta U_{k+1}\right)$ を求める式の中には， $U_{0 k}$ また は $\left(\boldsymbol{U}_{0 k}, \boldsymbol{U}_{0 k+1}\right)$ 自身が含まれている。それゆ元， $U_{k},\left(\boldsymbol{U}_{k}\right.$, $\left.U_{k+1}\right)$ が数值計算上の発散現象を引き起こし，非線形連立 方程式が収束しなくなる場合がある。そこで，(5)〜（7) 式のUの要素についても，ある指定值を超えないような 工夫が必要であり，これについては次節で述る。

〈3・3〉制約条件を考慮した解法 （26）式の方程式は， 一般に， $a \leq b$ であるため，多くの解が存在する。以下て は，解の収束性を向上させることを目的として，この上う な横長の修正方程式の解を求める新しい計算方法について 示す。

（1）第 1 段計算（前進消去過程）前進消去過程て は末処理の行列要素の中から絶対值が最大のものをピボッ トとして選択し，消去計算を行う。このとき， $D, E, F ，$ $G$ の要素の中で, 既に制限值を超えているものがあれば, 非基底変数の扱いとする。

（2）第 2 段計算（後退代入過程）後退代入過程で はまず基底解を求める。次に線形計画法の考兄方を取り入 れ，非基底变数について計算を行って，基底変数の絶対値 が小さくなる上うな值を見いだす（付録 2 参照）。

（3）第 3 段計算（近似值の修正）（2）項により修 正量が求まれば,すべての変数について $x_{\mu} \rightarrow x_{\mu}+\Delta x_{\mu}(\mu$
$=1,2, \cdots)$ として近似值の修正を行引。このとき， $x_{\mu}$ が制 限值を超えれば強制的に制限值に䈯換する。

以上のような計算を行い, 強制的に制限值にシフトした 変数もなく，かつすべての $\left|\Delta x_{\mu}\right|$ が指定した収束判定条件 ઘ以下であ机ば， $て \tau+\Delta \tau$ として次のステップの計算に 移る。特に，(2)項において非基底变数を計算するのは， $\max _{\mu}\left|\Delta x_{\mu}\right|$ を小さくするのが目的であるから，少ない反復 回数で, $\max \left|A x_{\mu}\right|<\varepsilon$ とすることが可能となる。

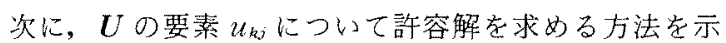
す。(27)式で, $\Delta \bar{U}=\operatorname{col}\left[\Delta \vec{U}_{s}, \Delta \vec{U}_{c}\right]$ とするただし, $\Delta \widetilde{U}_{s}, \Delta \widetilde{U}_{c}$ の要素は, 各々 $\left|u_{k j}\right|>u_{M}$, 扔よび $\left|u_{k j}\right| \leq u_{M}$ を 満足するものとする。ここに, $(k=1, \cdots, q, j=1, \cdots, n)$ と し, $u_{M}$ は $u_{k, j}$ の制限值を示す。 $A_{2}, \Delta \varepsilon_{2}^{*} \Delta \tilde{U}_{s}, \Delta \tilde{U}_{c} に$ 対匛して

$$
A_{2} \rightarrow\left[\begin{array}{l}
A_{21} \\
A_{22}
\end{array}\right], \quad \Delta \varepsilon_{2}^{*} \rightarrow\left[\begin{array}{l}
\Delta \varepsilon_{21}^{*} \\
\Delta \varepsilon_{22}^{*}
\end{array}\right]
$$

のように並べ換えると次式を得る。

$$
A_{21} \boldsymbol{X}=\Delta \tilde{U}_{s}-\Delta \varepsilon_{21}^{*}
$$

(26)式と(29)式とを合わせて解けば，指定した $\Delta \widetilde{U}_{s} に な$ るような解が得られる。実際には，的より内側の領域 (追込み域)に入るように $\Delta u_{k j}\left(\in \Delta \widetilde{U}_{s}\right)$ を指定する。ただ し，|$\left|u_{k, j}\right|$ が $u_{M}$ を大き超えている場合には，1回の計算 で追込み域内に収めようとすると，(29)式の右辺が大きく なることがある。その結果, 修正量が大きくなりすぎて, 他の $U$ の要素が制限值を超過する場合があるので，1段 の計算での追込み㽬には制約を課す必要がある。

\section{4. 適用検討例}

本章では，前章までに述べた方法を用いて，文献(6)て 示した 4 機一無限大系統を基にDCを設計し，シミュレー ションによって，その有効性を確認する。系統構成を図 1 に, 発電機定数表 1 亿, 励磁制御系の構成を図 2 に示 す。図1で $G_{5}$ は無限大系統を表し，事故点は@および○ の2䇢所を考之る。ただし，事故はそれぞれ独立に発生す るものとし，系統は 1 回線に三相短絡事故が発生してから $70 \mathrm{~ms}$ 後に三相遮断を行うものとする。

なお，以下では@および(b点上の送電線を便宜上，電源 線抢よび連系線と称する。DC設置前の電源線および連系 線を一回線遮断した後の主な固有值を表 2 に示す。

いずれの場合も正の固有值が含まれて招り，不安定で西 る。実際, シミュレーションを行うと, 電源線事故, 連采 線事故とも脱調した。その結果の一例（電源線事故）を図 3 に示す。このような系統に対して，以下ではDCを用い て安定化を図ることを試みる。ここでは，中央にコントロ 一ラ (DC) を配し，入出力信号を高速な通信回線を介し て集配する集中制御系考える。

DCに加える信号性 PSSで用いる各発電機の有効出力 $\left(P_{e}\right)$ と角速度 $(\omega)$ の活加, 無効出力 $\left(Q_{e}\right)$, 電流 $\left(I_{g}\right)$, なら びに連系線を通過する有效電力 $\left(P_{L}\right)$ と無効電力 $\left(Q_{L}\right)$ とす 
る。従って, DCへの入力信号は合計 18 となる。集中制 御システムを仮定すると，多入力系のシステムは 1 入力系 問題に変換できる。すなわち，A 㹥巡回的であるとし， ベクトル $\boldsymbol{\xi}\left(\boldsymbol{\xi} \in R^{r}\right)$ を用いて $\boldsymbol{b}=\boldsymbol{B} \boldsymbol{\xi}$ を求める。この $\boldsymbol{b}$ 在 (1)式の $\boldsymbol{B}$ の代和りに用いれば 1 入力系問題となる。こ こで, そは $G_{1} \sim G_{4}$ の制御分担比率を示し, 発電機容䑁, 制御系の性能, 各発電機の系統上の位置, 事故点などを勘 案して次のように設定した。
(i) 電源線遮断 $: \xi=\left[\begin{array}{llll}1.0 & 0.9 & 0.25 & 0.5\end{array}\right]^{r}$

(ii) 連系線遮断: $\boldsymbol{\xi}=\left[\begin{array}{llll}1.0 & 0.9 & 0.4 & 0.7\end{array}\right]^{T}$

DC の必要次数は，(15) 式に上机ば $q \geq 1$ となる。しかし, 実際には入力信号に含まれる情報の豊富さの度合や，DC パラメータの制約条件などにより, 解が得られた最小次数 は 4 となった。以下ではDCの次数を 4 として議論する。

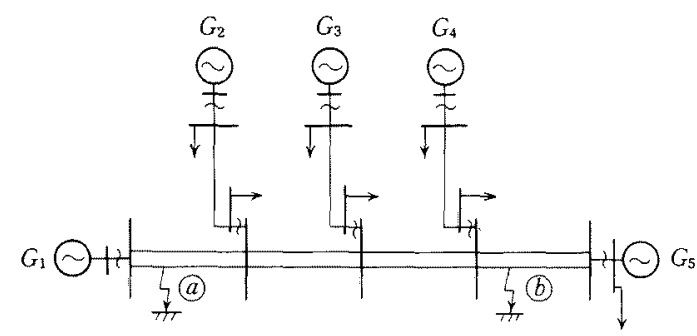

図 15 機系統

Fig. 1. Five-machine system

表 1 発電機定数

Table 1. Parameters of generator

\begin{tabular}{c|c|c|c|c|c}
\hline & $G_{1}$ & $G_{2}$ & $G_{3}$ & $G_{4}$ & $G_{5}$ \\
\hline MVA & 1334 & 1334 & 632 & 1556 & $1.1 \times 10^{6}$ \\
$M$ & 9.60 & 9.81 & 10.44 & 7.41 & 10.00 \\
$x_{d}$ & 1.450 & 1.670 & 1.100 & 1.778 & 1.580 \\
$x_{d}^{\prime}$ & 0.300 & 0.394 & 0.22 & 0.286 & 0.240 \\
$x^{\prime \prime}{ }_{d}$ & 0.243 & 0.304 & 0.160 & 0.230 & 0.219 \\
$x_{q}$ & 1.450 & 1.670 & 0.760 & 1.778 & 1.580 \\
$x^{\prime}{ }_{q}$ & 1.233 & 1.420 & 0.646 & 1.513 & 0.918 \\
$x^{\prime \prime}{ }_{q}$ & 0.243 & 0.304 & 0.160 & 0.230 & 0.219 \\
$R_{t}$ & 0.0013 & 0.0019 & 0.0017 & 0.002 & 0.0016 \\
$x_{t}$ & 0.199 & 0.217 & 0.080 & 0.207 & 0.184 \\
$T^{\prime}{ }_{d 0}$ & 6.140 & 6.150 & 8.580 & 4.850 & 5.00 \\
$T^{\prime \prime}{ }_{d 0}$ & 0.03 & 0.026 & 0.044 & 0.037 & 0.437 \\
$T^{\prime}{ }_{\phi 0}$ & 0.750 & 0.650 & 1.100 & 0.540 & 0.500 \\
$T^{\prime \prime}{ }_{q 0}$ & 0.100 & 0.090 & 0.150 & 0.07 & 0.070 \\
\hline
\end{tabular}

次に，固有值の改善目標として，モード $1 \sim 4$ を表 3 の ように設定し，残りの固有值はそのまま据え置いた。な お，DCの固有值はシステムと重複しないように選定 し, $-7.5,-8.0,-8.5,-9.0$ とした。

次に, DC 設計のために, $\boldsymbol{D}=\left[d_{i j}\right], \boldsymbol{F}=\left[f_{i j}\right]$ 扔よび $\boldsymbol{U}$ $=\left[u_{i j}\right]$ の各々の要素に課吉制約条件法,

$$
\begin{array}{ll}
\left|d_{i j}\right| \leq 500 & (i=1, \cdots, q, \quad j=1, \cdots, q) \\
\left|f_{i j}\right| \leq 15 & (i=1, \cdots, r, \quad j=1, \cdots, q) \\
\left|u_{i j}\right| \leq 50 & (i=1, \cdots, q, \quad j=1, \cdots, n)
\end{array}
$$

とする。また， $\boldsymbol{E}=\left[e_{i j}\right], \boldsymbol{G}=\left[g_{i j}\right]$ に対しては，用いる信 号の種別に応じて, 対応する行要素の絶対值の最大值を表 4 で示された值以下となるような制約を課した。ただし， $G_{1} \sim G_{4}$ について同じ種別の信号には同一の制約を課した。

次に, DC パラメー夕設計計算の初期值 (出発值) とし て次の値を用いた。ただ, $R(\sigma)$ は $(-1,1)$ の擬似乱数 を表す。

$$
\begin{array}{ll}
d_{i j}^{0}=3.0 \times R(\sigma)-0.05 & (i=1, \cdots, q, \quad j=1, \cdots, q) \\
e_{i j}^{0}=-0.3 \times R(\sigma)-0.2 & (i=1, \cdots, q, \quad j=1, \cdots, m) \\
f_{i j}^{0}=-0.1 \times R(\sigma)-0.05 & (i=1, \cdots, r, \quad j=1, \cdots, q) \\
g_{i j}^{0}=-0.1 \times R(\sigma)-0.01 & (i=1, \cdots, r, \quad j=1, \cdots, m)
\end{array}
$$

\begin{tabular}{|c|c|c|}
\hline モード & 電源線遮断 & 連系線㜯断 \\
\hline 1 & $0.285+j 4.705$ & $0.275+j 4.314$ \\
\hline 2 & $-0.229+j 6.506$ & $-0.267+j 6.410$ \\
\hline 3 & $-0.512+j 7.049$ & $-0.512+j 7.676$ \\
\hline 4 & $-0.536+j 7.547$ & $-0.541+j 7.230$ \\
\hline
\end{tabular}

表 2 主要な固有値

Table 2. Main eigenvalues of power swing.

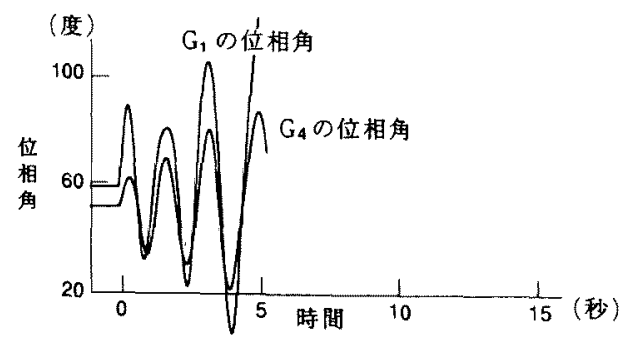

図 3 電源線一回線事故時の位相角変動 (DCなし) Fig. 3. Phase angle profile for three-phase-fault on $G_{1}$-line of single circuit (without DC).

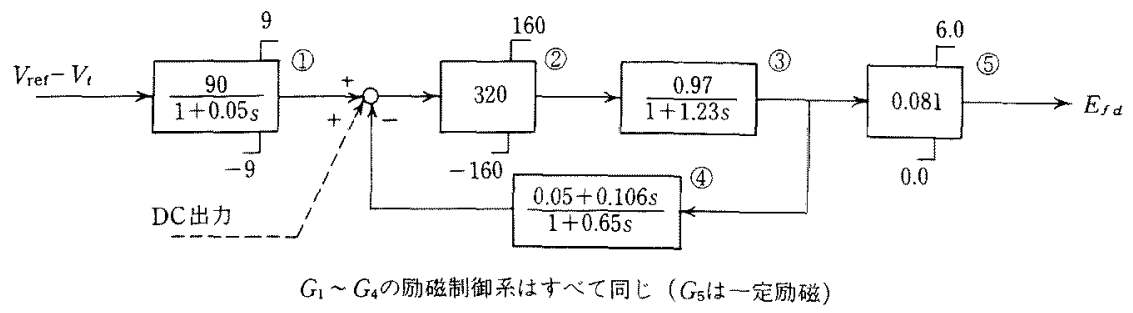

区 2 励磁制御系

Fig. 2. Block diagram of excitation system. 
表 3 望ましい固有值

Table 3. Desired eigenvalues.

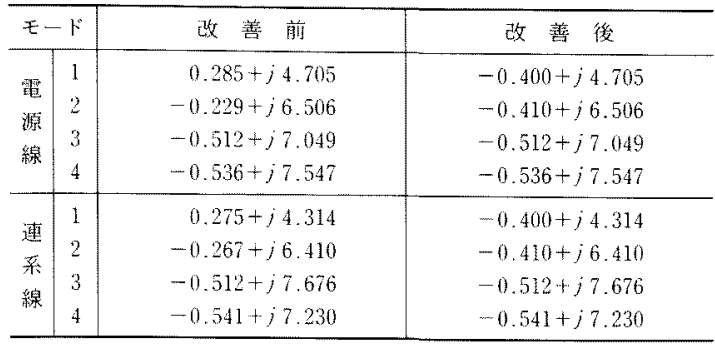

表 $4 E, G$ O制約条件

Table 4. Constraints of $E$ and $G$.

\begin{tabular}{c|c|c|c|c|c|c}
\hline $\mathrm{DC}^{\text {剩御信号 }}$ & $\begin{array}{c}\omega \\
(\mathrm{rad} / \mathrm{s})\end{array}$ & $\begin{array}{c}P_{e} \\
(\mathrm{pu})\end{array}$ & $\begin{array}{c}Q_{e} \\
(\mathrm{pu})\end{array}$ & $\begin{array}{c}I_{g} \\
(\mathrm{pu})\end{array}$ & $\begin{array}{c}P_{\mathrm{L}} \\
(\mathrm{pu})\end{array}$ & $\begin{array}{c}Q_{\mathrm{L}} \\
(\mathrm{pu})\end{array}$ \\
\hline$E$ & 8.0 & 4.0 & 2.0 & 2.0 & 4.0 & 4.0 \\
\hline$G$ & 2.7 & 2.0 & 1.0 & 1.0 & 2.0 & 2.0 \\
\hline
\end{tabular}

基準電力: $1,000 \mathrm{MVA}$

$$
\begin{aligned}
& u_{i j}^{0}=0.3 \times R(\sigma) \quad(i=1, \cdots, q, j=1, \cdots, n) \\
& \Delta \tau^{0}=10^{-4}
\end{aligned}
$$

以上の条件で，電源線事故に対応するDCの設計結果 を，表 5 に示す。ここで， $F^{\prime} ， G^{\prime}$ は，1 入力系問題とし て得られた $F, G$ に対応する結果を示す。な㧍， $E$ は要 素数が多いため, 表 5 八記載することを省略した。連系線 事故のケースについても同じようにDCを設計することが できる。

このような DC を多機系統に適用する場合には，想定さ れる様久な系統条件や事故条件 (事故地点, 事故種別) に 対して，安定化が図れることを確認しておく必要がある。 ある特定の系統条件および事故条件を想定して，DC を設 計したとき，それと異なる状況のときには，制御対象のパ ラメータが変動したのと等価な状態となる。それ沛え, 仮 に現用のPSSのように，固定したDCパラメータで制御 する場合には, 上述の上うな制御対象のパラメータ変動に 対する，ロバスト性について検討することが必要である。 このようなロバスト性の問題について考察するため, ここ では, 事故条件として典型的な, 電源線事故と連系線事故 の場合を取り上げ，次の二つのケースについて検討する。

ケース $a:$ 連系線対応の DC を電源線事故に用いる。 ケース $b$ : 電源線対応の DC を連系線事故に用いる。 表6より，ケース $a ， b$ とも，安定化は図れているが, ケース $a$ では, 制御性能の劣化が大きくなっている。従 って, 実際においては, 電源線事故を想定して設計した DCを，共通的に用いて制御することとなる。ただし，ケ 一ス $b$ の結果が，制御性能として不十分と判断される場 合には，DCの設計条件を修正して，再設計することが必 要となる。なお，このようなロバス卜性を向上させるため の一つの方法として, 文献(6)に示したような制御方式の 適用が考えられる。これは, 想定される系統条件抢よび事 故条件に対し，あらかじめ DCパラメータを設計してお
表 5 設計されたDCパラメータ

Table 5. Design parameters of DC.

\begin{tabular}{r|rcrccc}
\hline 列 & 1 & 2 & 3 & 4 & 5 & 6 \\
番 & 7 & 8 & 9 & 10 & 11 & 12 \\
& \multicolumn{1}{c}{13} & 14 & 15 & 16 & 17 & 18 \\
\hline \multirow{5}{*}{$D$} & -7.43 & -0.03 & 0.08 & 0.01 & & \\
& -47.02 & -7.71 & -0.75 & -0.07 & & \\
& 64.19 & 64.35 & -12.59 & -0.39 & & \\
\hline$F^{\prime}$ & -2.97 & 21.38 & -46.70 & -6.99 & & \\
\hline \multirow{5}{*}{$G^{\prime}$} & 0.68 & -3.41 & -1.81 & 10.75 & & \\
& -3.20 & -0.76 & 0.28 & -0.03 & -1.67 & -1.37 \\
& 1.49 & -0.01 & 5.38 & -0.77 & 0.51 & -0.00 \\
& 5.09 & -0.65 & 0.28 & 0.03 & 0.80 & -0.00 \\
\hline
\end{tabular}

表 6 固定のDCパラメータで制御したときの固有值 Table 6. Eigenvalues in controlling with fixed DC parameters.

\begin{tabular}{c|c|c}
\hline モード & ケース $a$ & ケース $b$ \\
\hline 1 & $-0.006+j 4.857$ & $-0.154+j 3.928$ \\
2 & $-0.357+j 6.597$ & $-0.312+j 6.300$ \\
3 & $-0.541+j 7.030$ & $-0.514+j 7.270$ \\
4 & $-0.525+j 7.544$ & $-0.594+j 7.686$ \\
\hline
\end{tabular}

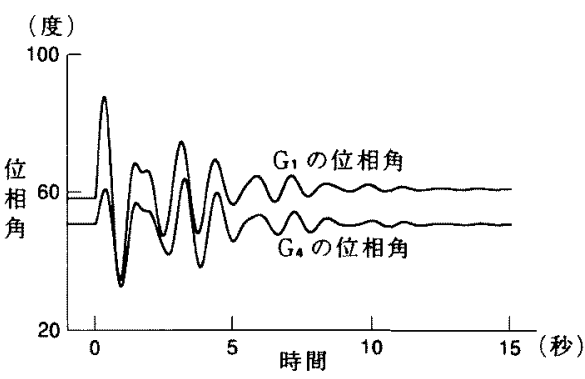

図 $4 G_{1}$ における三相短絡事故時の位相角 (DC 付加)

Fig. 4. Phase angle for three-phase-fault on $G_{1}-$ line of single circuit (with DC).

き，情報伝送回線を通して得た，実際の系統情報や事故情 報に照らして, 最も適切なパラメー夕を選択して, 制御す る方式となっている。

表 5 のような DCを用いて安定化制御を行ったときのシ ミュレーション結果を図 4 に示す。この図からわかるよう に，本手法に上ると電力動摇が収まっている。な挹，DC の出力段にはリミッタを設け, 出力レベルはー7.5〜7.5 puとした。これは，あまり大きな端子電圧変動を与えな いためである。

ここで，本論文で述べた設計手法の有効性を検討するた め, 電源線遮断のケースを対象に以下の検討を行う。

（i）本手法と文献（6)扔よび文献（7）の設計手法との 比較。

(ii) 〈3・3〉節で示した計算方法と, $\boldsymbol{D}, \boldsymbol{E}, \boldsymbol{F}, \boldsymbol{G}$ の制 約を考慮し，かつ，基底解たけを求める計算方法(A 方 法と呼ぶ）との比較。

まず（i ）について考える。文献（6)の手法では，DCパ 
表 $7\langle 3 \cdot 3\rangle$ 節の計算方法とA 方法との比較

Table 7. Comparison of Sec. $\langle 3 \cdot 3\rangle$ method with the A-method.

\begin{tabular}{|c|c|c|c|}
\hline 計算方法 & $\begin{array}{l}\text { 収柬与る迄の } \\
\text { 繰返し回数 }\end{array}$ & $\begin{array}{c}\text { 桴十算時間 } \\
\text { (秒) }\end{array}$ & $\begin{array}{l}\left.\left|u_{n j}\right| Q\right\rangle \\
\text { 最大徝 }\end{array}$ \\
\hline $\begin{array}{l}\langle 3 \cdot 3\rangle 0 \\
\text { 棓十算方法 }\end{array}$ & 277 & 112 & 44.7 \\
\hline A 方法 & 1,165 & 449 & 10.586 \\
\hline
\end{tabular}

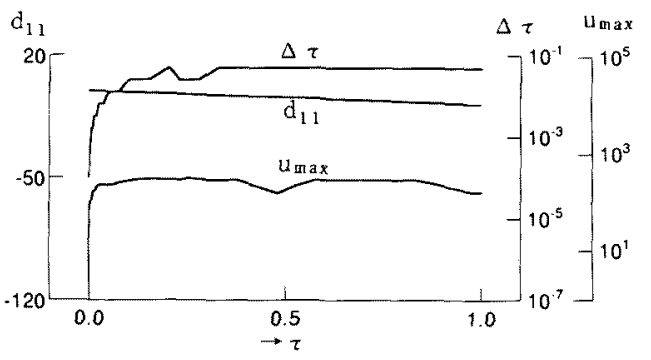

図 5 連続変形法による $d_{11}, \Delta \tau, u_{\max }$ の変化 $(\langle 3 \cdot 3\rangle$ 節の計算方法 $)$

Fig. 5. $d_{11}, \Delta \tau$ and $u_{\max }$ caluculated by the homotopy method (Sec. $\langle 3 \cdot 3\rangle$ method).

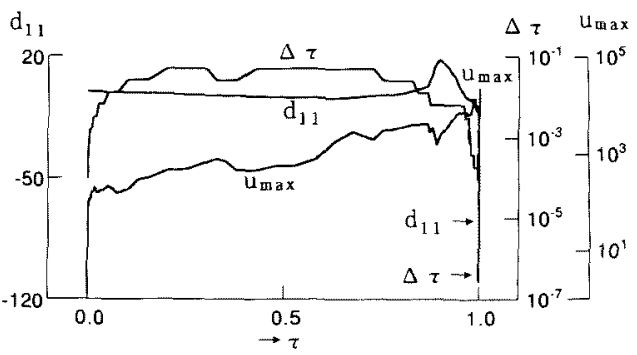

図 6 連続変形法による $d_{11}, \Delta \tau, u_{\max }$ の変化 (A 方法)

Fig. 6. $d_{11}, \Delta \tau$ and $u_{\max }$ caluculated by the homotopy method (A-method).

ラメータの決定は初期値に大きく依存しており，表 5 の値 を中心として士50\%程度以上の掑動を与えると望ましい固 有值配置林困難となった。

次に, 文献(7) は, 次の連立一次方程式を解いて DCパ ラメータを定めるものである。

$\phi \delta=\beta$

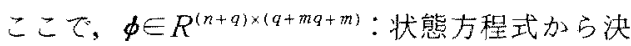

定される係数行列, $\beta \in R^{n+q}$ : 固有多項式加

決定される定数べクトル， $\boldsymbol{\delta} \in R^{q+m q+m}: \mathrm{DC}$ パ

ラメー夕決定す石変数べクトル

この手法では，前述の例に対して不完全な固有值配置しか できなかった。その理由は， $\phi, \delta の$ 要素の絶対值に大き な広がりを生じ, 計算機の有効桁数の制約より計算精度が 著しく劣化したなめと考之る。すなわち，中の要素の絶対 值は, $2 \times 10^{-3} \sim 8 \times 10^{44}, \beta$ \& $3 \times 10^{2} \sim 5 \times 10^{38}$ の幅を有し ていた。この結果，倍精度演算でも桁落ちが生じていた。 実際，(33)式から反を求め, これを再び(33)式に代入す

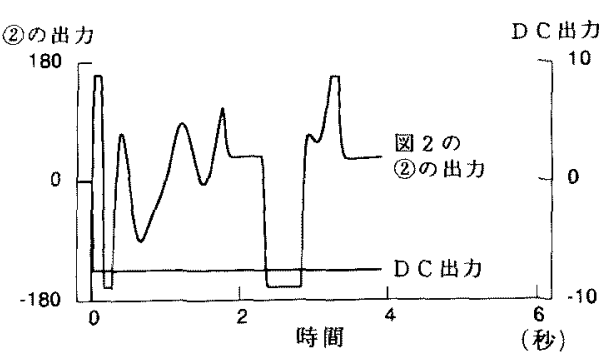

図 7 励磁制御系の動特性（A 方法） Fig. 7. Dynamic propery of excitation control system (A-method)

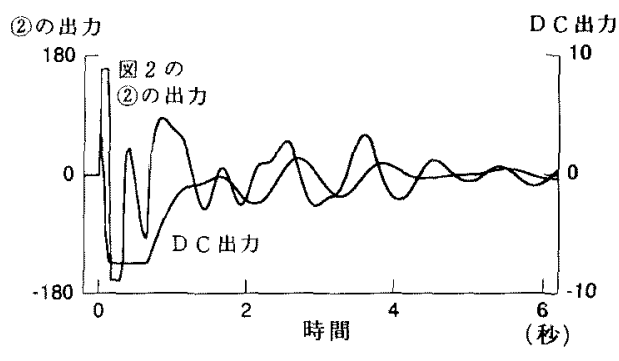

図 8 励磁制御系の動特性 (〈3・3〉節の方法)

Fig. 8. Dynamics of excitation control system (Sec. $\langle 3 \cdot 3\rangle$ method).

ると, 与えられていた $\beta$ との誤差の最大は $6 \times 10^{32}$ にも達 していた。このように文献（7)の方法は, 対象システムの 次数が高くなると, 計算精度の劣化が著しくなって実用が 困難となっている。

次に，(ii）について検討する。表 7 にく3・3〉節の方法と A 方法で処理した結果の比較を示す。また，図 5 ，図 6 は各々の手法について， $\tau=[0,1]$ 閒の $d_{11}, \Delta \tau$ ならびに $\left|u_{k j}\right|$ の最大值 $\left(u_{\text {max }}\right)$ の推移過程示す。ただし, 図 5 , 図 6 洛 $\tau$ に㭁いて収束した結果をつないだものである。 表 7 からわかるように, 非基底変数を利用して解の改善 を図るとともにUの要素にも制約定加えることにより解 の収束性が改善され，計算時間を短縮できることがわか る。また，|u知 $\mid$ の最大值を抑えることにより制御性能に 好影響を与えることができる。実際，A方法で求めた DC を用いてシミェレーションした結果は，不安定となった。 その原因は図７に示吉ように制御入力が大きくなり，DC の出力が飽和レべルに継続的に達しているためである。 〈3・3〉節の計算方法に上れば，DC の出力および図 20 (2) の出力とも図8に示すように飽和レベルに達している時間 は短時間であり, 急速に安定化制御機能を回復しているこ とがわかる。

\section{5.むすび}

本論文は，多機系統に㧍ける安定度向上を図るための実 用的な励磁制御系の構成方法を提案するとともに，シミュ レーションによりその有効性を示した。すなわち, 
（1）高機能化が要求されつつある矿磁制御に対し，多 变数制御系の考え方を有効に取り入れ，かつ厳密に取り扱 うために，低次元化したDCによる固有值を改善する方法 を用いた。

（2）このDC 実用的に設計できるようにするため， DC の関係式を直接数値計算し, その手段として大域的な 収束性に優れている連続変形法を適用する方法を提案し， その有効性を示した。

（3） DC の関係式に相似変換を行い，ニュートン法の 修正方程式を, 小サイズの連立方程式の求解問題に帰着し た。

（4）実際の励磁制御系には種々の非線形要素，とりわ け飽和要素が含まれるため，DCの設計にあたり，パラメ 一タの大きさに制䄪を課すことにより，実用的な DCが設 計できること，また，線形計画法の考方方を取り入れ，非 基底变数も操作することにより，収束性が改善できること を示した。

（5）本論文で提案した手法を 4 機一無限大系統に適用 し，その有効性を検証した。

なお，本論文では集中制御系についてのみ示したが，分 散制御系に対しても本手法は有效であると思われる。ただ し，適用にあたっては逐一的にDCを設計する必要があ る。このとき, DCの必要次数は対象となるシステムの次 数の影響を大きく受けるため，低次元化手法の導入が必要 である。これについては別の機会に報告する予定である。

(平成 6 年 10 月 24 日受付, 同 7 年 5 月 1 日再受付)

\section{文献}

(1) F, P. deMello \& C Concordia: "Concepts of Synchronous Machine as Affected by Excitation Control", IEEE Trans. Pouer Apparatus Syst., PAS-88, 316 (1969)

(2) W. Watson \& M. E. Couttes: "Static Exciter Stabilizing Signals on Lage Generators-Mechanical Problens", ibid., PAS92, $204(1973)$

(3) F. P. deMello, L. N. Hannett \& J. M. Undrill : "Practical Approaches to Supplementary Stabilizing from Accelerating Power", ibid., PAS-97, 1515 (1978)

(4) K. E. Bollinger, R. Winsor \& A. Campbell: "Frequency Response Methods for Tuning Stabilizers to Damp Out TieLine Power Oscillations", ibid., PAS-98, 1509 (1979)

（5）土井・网部：「多機采統におけるPSSの協調設部法」，電学諭 B, 81, 655 (昭 58)

（6）杉本，他：「励喛采，タービン，制動抵抗器を統合した適応形 制御方式任よる安定度の问上」，问上B，110，933（昭 61）

(7) F M. Brasch \& J. B. Pearson: "Pole Placement Using Dynamic Compensators", IEEE Trans. Automatic Control, AC-15, 34 (1970)

(8) K. Shimize, M. Suzuki \& M. Kato: "A Design Procedure for Asymptotically Optimal Dynamic Compensators", Trans. ASME J. Dynamic Syst., Meas. \& Control, 112, No. 1, 10 (1990)

（9）㖕測自動制御学会編：自動制御ハンドナック基砹諭，p. 140 (昭 58 ) 万一公社。

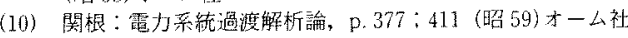

(11) 岩井, 他：オブザーバ, p.39(昭63)コロナ社

(12) 垐玉・須田：システム制御のためのマトリタス理論, p.228 (昭 53) 計測自㩆制御学会

（13）女藤，他：数唒解析手法に上る制御采設計，p.79；137(昭61) 計測自勳制御学全

（14）伊理：数値計算, p. 70:77（昭 63）朝會書店

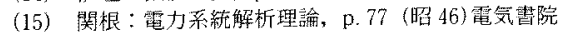

\section{付}

\section{録}

1. (26), (27) 式の導出

まず，单根の場合について考える。(24)式で， $L_{k}=D_{0}$ $-\operatorname{diag}\left\{\alpha_{k}\right\}$ とすると, $\Delta \boldsymbol{U}_{k}$ は次のようになる。

$$
\Delta U_{k}=-L_{k}^{-1}\left(\Delta E \bar{C}_{k}+\Delta D U_{0 k}-\Delta \varepsilon_{2 k}\right)
$$$$
=M_{1 k} \Delta \tilde{E}+M_{2 k} \Delta \bar{D}+\Delta \varepsilon_{2 k}^{*}
$$

ただし，

$$
\begin{aligned}
& M_{1 k}=-L_{k}^{-1}\left[\begin{array}{ccc}
C_{k}^{T} & & 0 \\
& \ddots & \\
0 & & C_{k}^{T}
\end{array}\right] \\
& M_{2 k}=-L_{k}^{-1}\left[\begin{array}{ccc}
U_{0 k}^{T} & & 0 \\
& \ddots & \\
0 & & U_{0 k}^{T}
\end{array}\right]
\end{aligned}
$$

$\Delta \varepsilon_{2 k}^{*}=\boldsymbol{L}_{k}^{-1} \Delta \varepsilon_{2 k}$

複素根の場合には， $\Delta \boldsymbol{U}_{k}$ と $\Delta \boldsymbol{U}_{k+1}$ をぺアとして解く必 要があるが，上と同じょうにして求めることができる。こ のようにして $\Delta U_{k} k=1$ 加 $n$ について求めると, $\Delta \tilde{U}$ は,

$$
\begin{aligned}
& \Delta \tilde{U}=M_{1} \Delta \tilde{E}+M_{2} \Delta \tilde{D}+\Delta \varepsilon_{2}^{*} \\
& =\left[\begin{array}{llll}
0 & 0 & M_{1} & M_{2}
\end{array}\right] X+\Delta \varepsilon_{2}^{*} \\
& \boldsymbol{X}=\operatorname{col}[\Delta \tilde{\boldsymbol{G}}, \Delta \tilde{\boldsymbol{F}}, \Delta \tilde{\boldsymbol{E}}, \Delta \tilde{\boldsymbol{D}}] \\
& M_{1}=\left[\begin{array}{l}
\boldsymbol{M}_{11} \\
\vdots \\
\boldsymbol{M}_{1 n}
\end{array}\right], \quad \boldsymbol{M}_{2}=\left[\begin{array}{l}
\boldsymbol{M}_{21} \\
\vdots \\
\boldsymbol{M}_{2 n}
\end{array}\right], \quad \Delta \varepsilon_{2}^{*}=\left[\begin{array}{l}
\Delta \varepsilon_{21}^{*} \\
\vdots \\
\Delta \varepsilon_{2 n}^{*}
\end{array}\right]
\end{aligned}
$$

となり，本文(27)式が得られる。

次に, (21)，(23)式に扝いて, $\boldsymbol{V}=\left(v_{i j}\right] \triangleq \overline{\boldsymbol{B}} \boldsymbol{F}_{0}, \boldsymbol{W}=$ $\left(w_{i j}\right) \triangleq \boldsymbol{U}_{0} \overline{\boldsymbol{B}}, \boldsymbol{F}_{0}=\operatorname{col}\left[\boldsymbol{F}_{01} \cdots \boldsymbol{F}_{0 r}\right], \Delta \varepsilon_{1}=\left[\Delta \varepsilon_{11} \cdots \Delta \varepsilon_{1 n}\right], \Delta \varepsilon_{3}$ $=\left[\Delta \varepsilon_{31} \cdots \Delta \varepsilon_{3 q}\right]$ とする。行列形式で与えられている(21), (23)式の方程式をべタトル形式で表すと，各々次の上うに なる。

$$
\begin{aligned}
& S_{11} \Delta \tilde{G}+S_{12} \Delta \tilde{F}+S_{13} \Delta \tilde{U}=\Delta \tilde{\varepsilon}_{1} \\
& I_{q}^{2} \Delta \tilde{D}+S_{21} \Delta \tilde{F}+S_{22} \Delta \tilde{U}=\Delta \tilde{\varepsilon}_{3}
\end{aligned}
$$

ここで, $\boldsymbol{I}_{q}^{2} は q^{2} \times q^{2}$ の単位行列を示している。また， $S_{11}, S_{12}, S_{13}, S_{21}, S_{22}, \Delta \tilde{\varepsilon}_{1}, \Delta \tilde{\varepsilon}_{3}$ は，次式で与えられる。

$$
\begin{aligned}
& S_{11}=\left[\begin{array}{ccc}
C^{T} & & 0 \\
& \ddots & \\
0 & & C^{T}
\end{array}\right], \quad S_{12}=\left[\begin{array}{ccc}
U_{0}^{T} & & 0 \\
& \ddots & \\
0 & & U_{0}^{T}
\end{array}\right] \\
& \boldsymbol{S}_{13}=\left[\begin{array}{c}
\boldsymbol{P}_{1} \\
\vdots \\
\boldsymbol{P}_{r}
\end{array}\right], \quad \boldsymbol{S}_{21}=\left[\begin{array}{ccc}
w_{11} \boldsymbol{I}_{q} & \cdots & w_{1 r} \boldsymbol{I}_{q} \\
\vdots & & \vdots \\
w_{q 1} \boldsymbol{I}_{q} & \cdots & w_{q r} \boldsymbol{I}_{q}
\end{array}\right] \\
& S_{22}=\left[\begin{array}{lll}
Q_{11} & \cdots & Q_{1 n} \\
\vdots & & \vdots \\
Q_{q 1} & \cdots & Q_{q n}
\end{array}\right] \\
& \Delta \widetilde{\varepsilon}_{1}=\operatorname{col}\left(\Delta \varepsilon_{11} \cdots \Delta \varepsilon_{1 n}\right) \\
& \Delta \widetilde{\varepsilon}_{3}=\operatorname{col}\left(\Delta \varepsilon_{31} \cdots \Delta \varepsilon_{3 q}\right]
\end{aligned}
$$
ここに,

$$
\boldsymbol{P}_{k}=\left[\begin{array}{lll}
\boldsymbol{F}_{0 k} & & 0 \\
& \ddots & \\
0 & & \boldsymbol{F}_{0 k}
\end{array}\right] \quad(k=1, \cdots, r)
$$




$$
\begin{aligned}
& \boldsymbol{Q}_{i j}=\left(\begin{array}{ccccccc}
0 & \cdots & 0 & v_{j 1} & 0 & \cdots & 0 \\
\vdots & & & \vdots & \vdots & \\
0 & \cdots & 0 & v_{j q} & 0 & \cdots & 0
\end{array}\right) \\
& (i=1, \cdots, q, j=1, \cdots, n)
\end{aligned}
$$

（付 3 ),（付 4 ) 式に(付 2 ) 式を代入すると,

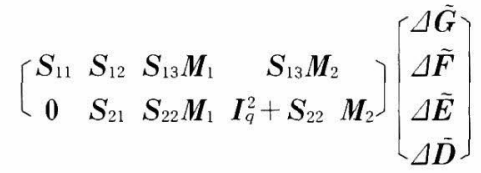

$$
\begin{aligned}
& =\left[\begin{array}{c}
\Delta \tilde{\varepsilon}_{1}-S_{13} \Delta \varepsilon_{2}^{*} \\
\Delta \tilde{\varepsilon}_{3}-S_{22} \Delta \varepsilon_{2}^{*}
\end{array}\right]
\end{aligned}
$$

上式から，(23)式の下三角部分に対応する $q(q-1) / 2$ 個 の方程式系を取り除くと本文(26)式となる。また，そのと きの右辺が定数べクトル $\Delta \varepsilon_{1}^{*}$ となる。

\section{2. 非基底变数の計算方法}

第 1 段目の計算終了後, (26) 式は次のような形に変形さ れている。

$$
\boldsymbol{H}_{1} \boldsymbol{X}_{\alpha}+\boldsymbol{H}_{2} \boldsymbol{X}_{\beta}=\boldsymbol{\gamma}
$$

ここで, $\boldsymbol{X}_{\alpha}, \boldsymbol{X}_{\beta}$ は，各々基底変数および非基底変数か らなるべクトルを表す。また， $H_{1} \in R^{a \times a}$ は基底行列を， $\boldsymbol{H}_{2} \in R^{a \times(b-a)}$ は非基底行列を, $\boldsymbol{\gamma}$ は, 消去過程で変形を 受けた(26)式の右辺の定数べクトルを示す。(付 7)式の $\boldsymbol{X}_{\alpha}, \boldsymbol{X}_{\beta}$ に対応する変数の添字集合を, 各 $N_{\alpha}, N_{\beta}$ とする。 いま，一つの非基底変数 $x_{s}$ の值を 1 とし，他のすべての 非基底変数を 0 としたときの, 基底変数 $x_{k}$ の変化量を $\gamma_{k s}$ で表す。ここで, 基底解を $\bar{x}_{k}, x_{\max } \triangleq \max _{k \in N a}\left|\bar{x}_{k}\right|$ とする。 $x_{\max }$ となる要素の番号を $p \in N_{\alpha}$ として， $x_{s}$ を，次のよう に求める。ここに， $\delta>0$ である。

(1) $\bar{x}_{p}$ と $\gamma_{p s}$ が同符号のとき

$$
\begin{aligned}
& x_{s}=\left\{\max _{k} \eta_{k} ;\left|\bar{x}_{p}+\gamma_{p s} \eta_{k}\right|=\left|\bar{x}_{k}+\gamma_{k s} \eta_{k}\right|,\right. \\
& \left.\forall k \in N_{a}, k \neq p,-\delta \leq \eta_{k} \leq 0\right\} \\
& \left.\forall k \in N_{\alpha}, k \neq p, 0 \leq \eta_{k} \leq \delta\right\}
\end{aligned}
$$

(付 8)式または(付 9)式より， $x_{s}$ が求まり，かつ $\left|\eta_{k}\right| \neq 0$ であれば $x_{\max }>\left|\bar{x}_{p}+\gamma_{p s} \eta_{k}\right|$ となる。このような計算をす

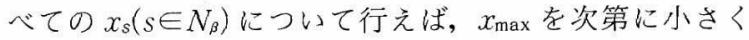
していくことが可能となる。

なお，ठは非基底変数の制限值を示すもので， $x_{\max }$ に 応じて定めるが， $\delta \leq x_{\max }$ となるように選ぶ必要がある。

松 下邦雄（正員） 1941 年 9 月 8 日生。1960 年 3 月四国電

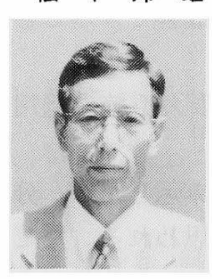
気高等学院卒業。同年 4 月四国電力(株) 入社。 現在, (株) 四国総合研究所主席研究員。電力系 統解析，制御に関する研究に従事。

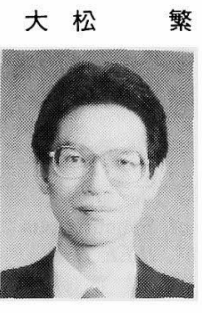

繁（正員） 1946 年 12 月 6 日生。 1974 年 3 月大阪 府立大学大学院工学研究科博士課程修了。同年 4 月徳島大学工学部情報工学科助手, 1988 年 4 月同教授。1995 年 4 月大阪府立大学情報工学科 教授となり，現在に至る。工学博士。適応制御， ニューラルネットなどの研究に従事。1991 年電 気学会論文賞, 1995 年計測自動制御学会論文賞 受賞。計測自動制御学会, SIAM, IEEE 会員。 